\title{
Sistem Pendukung Keputusan Menentukan Nasabah yang Layak Menerima Kredit Angsuran Pembiayaan Mekar di Kecamatan Medan Belawan pada PT. Permodalan Nasional Madani dengan Metode Analytical Hierarchy Process
}

\author{
Hendryan Winata, Mukhlis Ramadhan, Suardi Yakub, Marsono \\ "Sistem Informasi, STMIK Triguna Dharma
}

\section{Article Info}

Article history:

Received May $31^{\text {th }}, 2019$

Revised June $12^{\text {th }}, 2019$

Accepted Augs 05 ${ }^{\text {th }}, 2019$

\section{Keyword:}

Nasabah,Sistem

PendukungKeputusan,AHP,

Permodalan

\begin{abstract}
PT. Permodalan Nasional Madani merupakan solusi dari pemerintah untuk meningkatkan kesejahteraan masyarakat melalui pengembangan akses permodalan kredit angsuran. PT. Permodalan Nasional Madani masih mengalami masalah seperti pengambilan keputusan yang kurang efektif. Selain itu belum adanya program yang dapat membantu untuk menentukan Nasabah yang layak menerima kredit angsuran pembiayaan mekar pada PT. Permodalan Nasional Madani.

Untuk mempermudah dalam pemilihan Nasabah yang layak menerima kredit angsuran maka dapat menggunakan Sistem Pendukung Keputusan untuk menentukan Nasabah yang layak menerima kredit angsuran pembiayaan mekar di kecamatan Medan Belawan pada PT. Permodalan Nasional Madani dengan menggunakan kriteria dan Metode Analytical Hierarchy Process. Implementasi Sistem Pendukung Keputusan dengan pengujian sistem dapat membantu pihak PT. Permodalan Nasional Madani dalam menentukn nasabah yang layak menerima kredit angsuran pembiayaan mekar dikecamatan Medan Belawan secara cepat dan tepat.
\end{abstract}

Copyright @ 2019 STMIK Triguna Dharma. All rights reserved.

First Author

Nama :Hendryan Winata

Kantor :STMIK Triguna Dharma

Program Studi :Sistem Informasi

E-Mail :Hendryan@trigunadharma.ac.id

\section{PENDAHULUAN}

PT. Permodalan Nasional Madani (Persero) atau PNM, merupakan solusi dari pemerintah untuk meningkatkan kesejahteraan dan pemerataan ekonomi masyarakat melalui pengembangan akses permodalan dan program peningkatan kapasitas bagi para pelaku Usaha Mikro, Kecil, Menengah, dan Koperasi (UMKMK) guna menunjang pertumbuhan masyarakat yang ingin memulai usaha atau sudah memiliki usaha agar memiliki prospek usaha lebih meningkat.

PT. Permodalan Nasional Madani memberikan jasa pembiayaan secara langsung kepada nasabah. Perekrutan nasabah merupakan kegiatan mensurvei nasabah yang berhak menerima pinjaman sesuai kriteria yang sudah ditentukan oleh pihak perusahaan. Untuk itu PT. Permodalan Nasional Madani menetapkan beberapa syarat untuk menjadi nasabah sebelum mengajukan pinjaman dan calon nasabah harus menyiapkan syarat dan ketentuan yang sudah di tetapkan.

Dalam Proses perekrutan calon nasabah di PT. Permodalanan Nasional Madani masih dilakukan secara manual. Jika proses perekrutan masih dilakukan secara manual maka kurang efektif dan sering menimbulkan kesalahan. Maka dibutuhkan sistem yang dapat membantu pihak PT. Permodalan Nasional Madani untuk membantu mengambil keputusan untuk mengurangi tingkat kesalahan dalam mengambil keputusan.

\section{LANDASAN TEORITIS}

\subsection{Defenisi Sistem Pendukung Keputusan}


Menurut (Simanjorang, dkk 2017 : 23) "Sistem pendukung keputusan merupakan bagian dari sistem informasi berbasis komputer yang mengatasi masalah ini. Sistem ini dapat mendukung pengambilan keputusan calon penerima bahan pangan bersubsidi berdasarkan kriteria-kriteria yang telah ditentukan. Cara kerja sistem ini mencakup seluruh tahap pengambilan masalah, memilih data yang relevan dan menentukan pendekatan yang digunakan dalam proses pengambilan keputusan sampai pemecahan dan solusi masalah".

Adapun Komponen-komponen pada sistem pendukung keputusan adalah :

1. Data Management, termasuk database yang berisi data yang relevan dan diatur oleh software yang disebut database managemen sistem.

2. Model Management, termasuk model finansial,statistikal, managemen science, atau model kumulatif dan managemen software yang diperlukan.

3. Comunicattion, user dapat berkomunikasi dan memberikan perintah . melalui subsistem ini menyediakan antarmuka.

4. Knowledge Management,mendukung subsistem lain dan bertindak sebagai komponen yang berdiri sendiri.

\subsection{Metode AHP (Analytical Hierarchy Process)}

Menurut (Ardiyanto, dkk 2013 : 2) AHP (Analytic Hierarchy Process) adalah metode untuk memecahkan suatu situasi yang kompleks tidak terstruktur ke dalam beberapa komponen dalam susunan yang hirarki, dengan memberi nilai subjektif tentang pentingnya setiap variabel secara relatif dan menetapkan variabel mana yang memiliki prioritas paling tinggi guna mempengaruhi hasil pada situasi tersebut.

\subsection{Unified Modeling Language(UML)}

MenurutNugroho (2010:6), UML adalah bahasa pemodelan untuk system perangkat lunak yang beriorientasi objek. Pemodelan sesungguhnya digunakan untuk penyederhanaan permasalahan permasalahan kompleks sedemikian rupa sehingga lebih mudah dipelajari dan dipahami. Untuk mendapatkan banyak pandangan terhadap system informasi yang akan dibangun, UML menyediakan beberapa diagram visual yang menunjukkan berbagai aspek dalam system.

\subsection{BahasaPemrograman Visual Basic 2008}

Aplikasi pemrograman yang terkenal dan memiliki kelebihan yang sangat handal adalah Microsoft Visual Basic. Microsoft Visual Basic merupakan sebuah bahasa pemrograman komputer yang dimengerti komputer untuk melakukan tugas-tugas tertentu.

\subsection{Microsoft Access 2010}

Menurut Suarna Tata (2012:11) Microsoft Office Acces adalah salah satu program aplikasi database paling lengkap dang canggih saat ini. Dengan menggunakan Acces 2010 dapat membantu membuat database dengan mudah. Database Acces adalah suatu aplikasi yang berguna untuk mengorganisasi sejumlah datadata yang ada dengan model relational.

\section{Analisa dan Perancangan}

Dalam proses pemilihan calon penerima modal usaha yang akan dilakukan, alternatif ataupun peserta yang akan dipilih diantaranya :

Table 3.1 Tabel Alternatif

\begin{tabular}{|c|c|c|c|c|c|c|}
\hline Simbol & Nama & $\begin{array}{c}\text { Jumlah } \\
\text { Tanggungan }\end{array}$ & Penghasilan & $\begin{array}{c}\text { Status } \\
\text { Rumah }\end{array}$ & $\begin{array}{c}\text { Beban } \\
\text { Hutang }\end{array}$ & Usia \\
\hline A01 & $\begin{array}{c}\text { ADE IRMA } \\
\text { HASANAH LUBIS }\end{array}$ & 4 & Rp.1.500.000 & $\begin{array}{c}\text { Milik } \\
\text { Sendiri }\end{array}$ & $\begin{array}{c}\text { Tidak } \\
\text { ada }\end{array}$ & 30 \\
\hline A02 & $\begin{array}{c}\text { APRILIA } \\
\text { WULANDARI }\end{array}$ & 2 & Rp. 2.800.000 & Kontrak & $\begin{array}{c}\text { Tidak } \\
\text { ada }\end{array}$ & 28 \\
\hline A03 & $\begin{array}{c}\text { AYU RANTIKA } \\
\text { PUTRI }\end{array}$ & 1 & Rp. 3.000.000 & $\begin{array}{c}\text { Milik } \\
\text { Sendiri }\end{array}$ & $\begin{array}{c}\text { Tidak } \\
\text { ada }\end{array}$ & 45 \\
\hline A04 & $\begin{array}{c}\text { AYU RANTIKA } \\
\text { PANJAITAN }\end{array}$ & 4 & Rp.2.500.000 & $\begin{array}{c}\text { Milik } \\
\text { Sendiri }\end{array}$ & $\begin{array}{c}\text { Tidak } \\
\text { ada }\end{array}$ & 30 \\
\hline A05 & INDAH SARI & 2 & Rp. 2.800.000 & Kontrak & $\begin{array}{c}\text { Tidak } \\
\text { ada }\end{array}$ & 28 \\
\hline A06 & LISMA PUSPITA SARI & 3 & Rp. 3.200.000 & $\begin{array}{c}\text { Milik } \\
\text { Sendiri }\end{array}$ & $\begin{array}{c}\text { Tidak } \\
\text { ada }\end{array}$ & 45 \\
\hline
\end{tabular}




\begin{tabular}{|c|c|c|c|c|c|c|}
\hline A07 & NOVI PUSPA SARI & 4 & Rp.1.500.000 & $\begin{array}{c}\text { Milik } \\
\text { Sendiri }\end{array}$ & $\begin{array}{c}\text { Tidak } \\
\text { ada }\end{array}$ & 30 \\
\hline A08 & ARAFAH & 6 & Rp. 3.900.000 & Kontrak & $\begin{array}{c}\text { Tidak } \\
\text { ada }\end{array}$ & 28 \\
\hline A09 & NURMALA & 8 & Rp. 3.000.000 & $\begin{array}{c}\text { Milik } \\
\text { Sendiri }\end{array}$ & $\begin{array}{c}\text { Tidak } \\
\text { ada }\end{array}$ & 45 \\
\hline A10 & PUTRI NOVITA & 4 & Rp.1.800.000 & $\begin{array}{c}\text { Milik } \\
\text { Sendiri }\end{array}$ & $\begin{array}{c}\text { Tidak } \\
\text { ada }\end{array}$ & 30 \\
\hline
\end{tabular}

Adapun kriteria-kriteria yang digunakan dalam proses pemilihan Nasabah dengan menggunakan metode Analytic Hierarchy Process seperti tabel berikut ini :

Tabel 3.2 Tabel Kriteria

\begin{tabular}{|c|l|l|}
\hline No & \multicolumn{1}{|c|}{ Simbol } & \multicolumn{1}{c|}{ Kriteria } \\
\hline 1 & K1 & Jumlah Tanggungan \\
\hline 2 & K2 & Penghasilan \\
\hline 3 & K3 & Status Rumah \\
\hline 4 & K4 & Beban Hutang \\
\hline 5 & K5 & Usia \\
\hline
\end{tabular}

Tabel 3.3 Matriks Kriteria Berpasangan

\begin{tabular}{|c|c|c|c|c|c|}
\hline & K1 & K2 & K3 & K4 & K5 \\
\hline K1 & 1 & 2 & 2 & 2 & 0,5 \\
\hline K2 & 0,5 & 1 & 2 & 2 & 0,3333 \\
\hline K4 & 0,5 & 0,5 & 1 & 3 & 0,3333 \\
\hline K5 & 0,5 & 0,5 & 0,3333 & 1 & 0,3333 \\
\hline TOTAL & 2 & 3 & 3 & 3 & 1 \\
\hline $\mathbf{4 , 5}$ & $\mathbf{7}$ & $\mathbf{8 , 3 3 3 3}$ & $\mathbf{1 1}$ & $\mathbf{2 , 4 9 9 9}$ \\
\hline
\end{tabular}

Tabel 3.4 Matriks Perhitungan Nilai Elemen Dibagi Jumlah Kolom

\begin{tabular}{|c|c|c|c|c|c|c|}
\hline & K1 & K2 & K3 & K4 & K5 & TOTAL \\
\hline K1 & 0,222222 & 0,285714 & 0,240001 & 0,181818 & 0,200008 & 1,129764 \\
\hline K2 & 0,111111 & 0,142857 & 0,240001 & 0,181818 & 0,133325 & 0,809113 \\
\hline K3 & 0,111111 & 0,071429 & 0,12 & 0,272727 & 0,133325 & 0,708593 \\
\hline K4 & 0,111111 & 0,071429 & 0,039996 & 0,090909 & 0,133325 & 0,44677 \\
\hline K5 & 0,444444 & 0,428571 & 0,360001 & 0,272727 & 0,400016 & 1,905761 \\
\hline
\end{tabular}

Tabel 3.5 Matriks Perhitungan Eigen Vector

\begin{tabular}{|l|c|c|c|}
\hline \multicolumn{1}{|c|}{ Kriteria } & Total & Eigen Vektor & Rangking \\
\hline Jumlah Tanggungan & 1,129764 & 0,225953 & 2 \\
\hline Penghasilan & 0,809113 & 0,161823 & 4 \\
\hline Status Rumah & 0,708593 & 0,141719 & 3 \\
\hline Beban Hutang & 0,44677 & 0,089354 & 5 \\
\hline Usia & 1,905761 & 0,381152 & 1 \\
\hline
\end{tabular}

Tabel 3.6 Matriks Kriteria Jumlah Tanggungan Berpasangan

\begin{tabular}{|l|c|c|c|c|c|c|c|c|c|c|}
\hline & A01 & A02 & A03 & A04 & A05 & A06 & A07 & A08 & A09 & A10 \\
\hline A01 & 1 & 2 & 3 & 2 & 2 & 3 & 2 & 2 & 2 & 2 \\
\hline
\end{tabular}




\begin{tabular}{|l|c|c|c|c|c|c|c|c|c|c|}
\hline A02 & 0.5 & 1 & 2 & 3 & 3 & 2 & 2 & 2 & 3 & 3 \\
\hline A03 & 0.33 & 0.5 & 1 & 3 & 4 & 2 & 2 & 2 & 2 & 2 \\
\hline A04 & 0.5 & 0.33 & 0.33 & 1 & 2 & 2 & 2 & 3 & 3 & 3 \\
\hline A05 & 0.5 & 0.33 & 0.25 & 0.5 & 1 & 2 & 2 & 2 & 2 & 3 \\
\hline A06 & 0.33 & 0.5 & 0.5 & 0.5 & 0.5 & 1 & 3 & 2 & 2 & 3 \\
\hline A07 & 0.5 & 0.5 & 0.5 & 0.5 & 0.5 & 0.33 & 1 & 3 & 2 & 3 \\
\hline A08 & 0.5 & 0.5 & 0.5 & 0.33 & 0.5 & 0.5 & 0.33 & 1 & 3 & 2 \\
\hline A09 & 0.5 & 0.33 & 0.5 & 0.33 & 0.5 & 0.5 & 0.5 & 0.33 & 1 & 2 \\
\hline A10 & 0.5 & 0.33 & 0.5 & 0.33 & 0.33 & 0.33 & 0.33 & 0.5 & 0.5 & 1 \\
\hline TOTAL & $\mathbf{5 . 1 6}$ & $\mathbf{6 . 3 3}$ & $\mathbf{9 . 0 8}$ & $\mathbf{1 1 . 5}$ & $\mathbf{1 4 . 3 3}$ & $\mathbf{1 3 . 6 6}$ & $\mathbf{1 5 . 1 6}$ & $\mathbf{1 7 . 8 3}$ & $\mathbf{2 0 . 5}$ & $\mathbf{2 4}$ \\
\hline
\end{tabular}

Tabel 3.7 Matriks Perhitungan Eigen Vector Jumlah Tanggungan

\begin{tabular}{|l|c|c|c|c|c|c|c|c|}
\hline & A01 & A02 & A03 & A04 & A05 & A06 & A07 & A08 \\
\hline A01 & 0.19 & 0.32 & 0.33 & 0.17 & 0.14 & 0.22 & 0.13 & 0.11 \\
\hline A02 & 0.10 & 0.16 & 0.22 & 0.26 & 0.21 & 0.15 & 0.13 & 0.11 \\
\hline A03 & 0.06 & 0.08 & 0.11 & 0.26 & 0.28 & 0.15 & 0.13 & 0.11 \\
\hline A04 & 0.10 & 0.05 & 0.04 & 0.09 & 0.14 & 0.15 & 0.13 & 0.17 \\
\hline A05 & 0.10 & 0.05 & 0.03 & 0.04 & 0.07 & 0.15 & 0.13 & 0.11 \\
\hline A06 & 0.06 & 0.08 & 0.06 & 0.04 & 0.03 & 0.07 & 0.20 & 0.11 \\
\hline A07 & 0.10 & 0.08 & 0.06 & 0.04 & 0.03 & 0.02 & 0.07 & 0.17 \\
\hline A08 & 0.10 & 0.08 & 0.06 & 0.03 & 0.03 & 0.04 & 0.02 & 0.06 \\
\hline A09 & 0.10 & 0.05 & 0.06 & 0.03 & 0.03 & 0.04 & 0.03 & 0.02 \\
\hline A10 & 0.10 & 0.05 & 0.06 & 0.03 & 0.02 & 0.02 & 0.02 & 0.03 \\
\hline
\end{tabular}

Tabel 3.7 Matriks Perhitungan Eigen Vector Jumlah Tanggungan (lanjutan)

\begin{tabular}{|l|r|r|r|r|r|}
\hline & A09 & A10 & \multicolumn{1}{l|}{ Total } & \multicolumn{1}{l|}{ E. Vactor } & \multicolumn{1}{l|}{ Ranking } \\
\hline A01 & 0.10 & 0.08 & 1.80 & 0.18 & 1 \\
\hline A02 & 0.15 & 0.13 & 1.61 & 0.16 & 2 \\
\hline A03 & 0.10 & 0.08 & 1.36 & 0.14 & 3 \\
\hline A04 & 0.15 & 0.13 & 1.13 & 0.11 & 4 \\
\hline A05 & 0.10 & 0.13 & 0.90 & 0.09 & 5 \\
\hline A06 & 0.10 & 0.13 & 0.88 & 0.09 & 6 \\
\hline A07 & 0.10 & 0.13 & 0.79 & 0.08 & 7 \\
\hline A08 & 0.15 & 0.08 & 0.64 & 0.06 & 8 \\
\hline A09 & 0.05 & 0.08 & 0.49 & 0.05 & 9 \\
\hline A10 & 0.02 & 0.04 & 0.40 & 0.04 & 10 \\
\hline
\end{tabular}

Tabel 3.8 Matriks Kriteria Penghasilan Berpasangan

\begin{tabular}{|l|r|r|r|r|r|r|r|r|r|r|}
\hline & \multicolumn{1}{|l|}{ A01 } & A02 & A03 & A04 & A05 & A06 & A07 & A08 & A09 & A10 \\
\hline A01 & 1 & 2 & 0.5 & 2 & 0.5 & 3 & 2 & 0.5 & 0.5 & 2 \\
\hline A02 & 0.5 & 1 & 0.5 & 3 & 3 & 2 & 0.5 & 2 & 3 & 0.5 \\
\hline A03 & 2 & 2 & 1 & 3 & 0.5 & 0.5 & 2 & 2 & 0.5 & 2 \\
\hline A04 & 0.5 & 0.33 & 0.33 & 1 & 2 & 0.5 & 0.5 & 0.5 & 3 & 0.5 \\
\hline A05 & 2 & 0.33 & 2 & 0.5 & 1 & 2 & 2 & 2 & 0.5 & 3 \\
\hline A06 & 0.33 & 0.5 & 2 & 2 & 0.5 & 1 & 3 & 2 & 2 & 2 \\
\hline
\end{tabular}




\begin{tabular}{|l|r|r|r|r|r|r|r|r|r|r|}
\hline A07 & 0.5 & 2 & 0.5 & 2 & 0.5 & 0.33 & 1 & 3 & 3 & 3 \\
\hline A08 & 2 & 0.5 & 0.5 & 2 & 0.5 & 0.5 & 0.33 & 1 & 3 & 0.5 \\
\hline A09 & 2 & 0.33 & 2 & 0.33 & 2 & 0.5 & 0.33 & 0.33 & 1 & 3 \\
\hline A10 & 0.5 & 2 & 0.5 & 2 & 0.33 & 0.5 & 0.33 & 2 & 0.33 & 1 \\
\hline TOTAL & $\mathbf{1 1 . 3 3}$ & $\mathbf{1 1}$ & $\mathbf{9 . 8 3}$ & $\mathbf{1 7 . 8 3}$ & $\mathbf{1 0 . 8 3}$ & $\mathbf{1 0 . 8 3}$ & $\mathbf{1 2}$ & $\mathbf{1 5 . 3 3}$ & $\mathbf{1 6 . 8 3}$ & $\mathbf{1 7 . 5}$ \\
\hline
\end{tabular}

Tabel 3.9 Matriks Perhitungan Eigen Vector Penghasilan

\begin{tabular}{|l|c|c|c|c|c|c|c|c|}
\hline & A01 & A02 & A03 & A04 & A05 & A06 & A07 & A08 \\
\hline A01 & 0.09 & 0.32 & 0.06 & 0.17 & 0.03 & 0.22 & 0.13 & 0.03 \\
\hline A02 & 0.10 & 0.16 & 0.06 & 0.26 & 0.21 & 0.15 & 0.03 & 0.11 \\
\hline A03 & 0.39 & 0.32 & 0.11 & 0.26 & 0.03 & 0.04 & 0.13 & 0.11 \\
\hline A04 & 0.10 & 0.05 & 0.04 & 0.09 & 0.14 & 0.04 & 0.03 & 0.03 \\
\hline A05 & 0.39 & 0.05 & 0.22 & 0.04 & 0.07 & 0.15 & 0.13 & 0.11 \\
\hline A06 & 0.06 & 0.08 & 0.22 & 0.17 & 0.03 & 0.07 & 0.20 & 0.11 \\
\hline A07 & 0.10 & 0.32 & 0.06 & 0.17 & 0.03 & 0.02 & 0.07 & 0.17 \\
\hline A08 & 0.39 & 0.08 & 0.06 & 0.17 & 0.03 & 0.04 & 0.02 & 0.06 \\
\hline A09 & 0.39 & 0.05 & 0.22 & 0.03 & 0.14 & 0.04 & 0.02 & 0.02 \\
\hline A10 & 0.10 & 0.32 & 0.06 & 0.17 & 0.02 & 0.04 & 0.02 & 0.11 \\
\hline
\end{tabular}

Tabel 3.9 Matriks Perhitungan Eigen Vector Penghasilan (lanjutan)

\begin{tabular}{|l|r|r|r|r|r|}
\hline & A09 & \multicolumn{1}{|l|}{ A10 } & \multicolumn{1}{l|}{ Total } & \multicolumn{1}{l|}{ E. Vactor } & \multicolumn{1}{l|}{ Ranking } \\
\hline A01 & 0.02 & 0.08 & 1.16 & 0.12 & 5 \\
\hline A02 & 0.15 & 0.02 & 1.24 & 0.12 & 3 \\
\hline A03 & 0.02 & 0.08 & 1.50 & 0.15 & 1 \\
\hline A04 & 0.15 & 0.02 & 0.68 & 0.07 & 10 \\
\hline A05 & 0.02 & 0.13 & 1.31 & 0.13 & 2 \\
\hline A06 & 0.10 & 0.08 & 1.14 & 0.11 & 6 \\
\hline A07 & 0.15 & 0.13 & 1.21 & 0.12 & 4 \\
\hline A08 & 0.15 & 0.02 & 1.01 & 0.10 & 8 \\
\hline A09 & 0.05 & 0.13 & 1.08 & 0.11 & 7 \\
\hline A10 & 0.02 & 0.04 & 0.89 & 0.09 & 9 \\
\hline
\end{tabular}

Tabel 3.10 Matriks Kriteria status rumah Berpasangan

\begin{tabular}{|l|r|r|r|r|r|r|r|r|r|r|}
\hline & \multicolumn{1}{l}{ A01 } & \multicolumn{1}{l}{ A02 } & A03 & A04 & \multicolumn{1}{l}{ A05 } & A06 & A07 & A08 & A09 & A10 \\
\hline A01 & 1 & 2 & 0.5 & 2 & 0.5 & 3 & 2 & 0.5 & 0.5 & 2 \\
\hline A02 & 0.5 & 1 & 0.5 & 3 & 3 & 2 & 0.5 & 2 & 3 & 0.5 \\
\hline A03 & 2 & 2 & 1 & 3 & 0.5 & 0.5 & 2 & 2 & 0.5 & 2 \\
\hline A04 & 0.5 & 0.33 & 0.33 & 1 & 2 & 0.5 & 0.5 & 0.5 & 3 & 0.5 \\
\hline A05 & 2 & 0.33 & 2 & 0.5 & 1 & 2 & 2 & 2 & 0.5 & 3 \\
\hline A06 & 0.33 & 0.5 & 2 & 2 & 0.5 & 1 & 3 & 2 & 2 & 2 \\
\hline A07 & 0.5 & 2 & 0.5 & 2 & 0.5 & 0.33 & 1 & 3 & 0.5 & 3 \\
\hline A08 & 2 & 0.5 & 0.5 & 2 & 0.5 & 0.5 & 0.33 & 1 & 3 & 0.5 \\
\hline A09 & 2 & 0.33 & 2 & 0.33 & 2 & 0.5 & 2 & 0.33 & 1 & 3 \\
\hline A10 & 0.5 & 2 & 0.5 & 2 & 0.33 & 0.5 & 0.33 & 2 & 0.33 & 1 \\
\hline TOTAL & $\mathbf{1 1 . 3 3}$ & $\mathbf{1 1}$ & $\mathbf{9 . 8 3}$ & $\mathbf{1 7 . 8 3}$ & $\mathbf{1 0 . 8 3}$ & $\mathbf{1 0 . 8 3}$ & $\mathbf{1 3 . 6 7}$ & $\mathbf{1 5 . 3 3}$ & $\mathbf{1 4 . 3 3}$ & $\mathbf{1 7 . 5}$ \\
\hline
\end{tabular}


Tabel 3.11 Matriks Perhitungan Eigen Vector Status Rumah

\begin{tabular}{|c|c|c|c|c|c|c|c|}
\hline A01 & A02 & A03 & A04 & A05 & A06 & A07 & A08 \\
\hline 0.09 & 0.32 & 0.06 & 0.17 & 0.03 & 0.22 & 0.13 & 0.03 \\
\hline 0.10 & 0.16 & 0.06 & 0.26 & 0.21 & 0.15 & 0.03 & 0.11 \\
\hline 0.39 & 0.32 & 0.11 & 0.26 & 0.03 & 0.04 & 0.13 & 0.11 \\
\hline 0.10 & 0.05 & 0.04 & 0.09 & 0.14 & 0.04 & 0.03 & 0.03 \\
\hline 0.39 & 0.05 & 0.22 & 0.04 & 0.07 & 0.15 & 0.13 & 0.11 \\
\hline 0.06 & 0.08 & 0.22 & 0.17 & 0.03 & 0.07 & 0.20 & 0.11 \\
\hline 0.10 & 0.32 & 0.06 & 0.17 & 0.03 & 0.02 & 0.07 & 0.17 \\
\hline 0.39 & 0.08 & 0.06 & 0.17 & 0.03 & 0.04 & 0.02 & 0.06 \\
\hline 0.39 & 0.05 & 0.22 & 0.03 & 0.14 & 0.04 & 0.13 & 0.02 \\
\hline 0.10 & 0.32 & 0.06 & 0.17 & 0.02 & 0.04 & 0.02 & 0.11 \\
\hline
\end{tabular}

Tabel 3.11 Tabel Matriks Perhitungan Eigen Vector Status Rumah (lanjutan)

\begin{tabular}{|l|l|l|r|r|r|}
\hline & A09 & A10 & Total & \multicolumn{1}{l}{ E. Vactor } & Ranking \\
\hline A01 & 0.02 & 0.08 & 1.16 & 0.12 & 5 \\
\hline A02 & 0.15 & 0.02 & 1.24 & 0.12 & 3 \\
\hline A03 & 0.02 & 0.08 & 1.50 & 0.15 & 1 \\
\hline A04 & 0.15 & 0.02 & 0.68 & 0.07 & 10 \\
\hline A05 & 0.02 & 0.13 & 1.31 & 0.13 & 2 \\
\hline A06 & 0.10 & 0.08 & 1.14 & 0.11 & 6 \\
\hline A07 & 0.02 & 0.13 & 1.08 & 0.11 & 7 \\
\hline A08 & 0.15 & 0.02 & 1.01 & 0.10 & 8 \\
\hline A09 & 0.05 & 0.13 & 1.19 & 0.12 & 4 \\
\hline A10 & 0.02 & 0.04 & 0.89 & 0.09 & 9 \\
\hline
\end{tabular}

Tabel 3.12 Matriks Kriteria beban hutangBerpasangan

\begin{tabular}{|c|c|c|c|c|c|c|c|c|c|c|}
\hline & $\mathrm{A} 01$ & $\mathrm{~A} 02$ & $\mathrm{~A} 03$ & A04 & A05 & A06 & A07 & A08 & A09 & A 10 \\
\hline A01 & 1 & 2 & 0.5 & 2 & 0.5 & 0.5 & 2 & 0.5 & 2 & 2 \\
\hline $\mathrm{A} 02$ & 0.5 & 1 & 0.5 & 3 & 3 & 2 & 0.5 & 2 & 3 & 2 \\
\hline $\mathrm{A} 03$ & 2 & 2 & 1 & 3 & 0.5 & 0.5 & 2 & 2 & 0.5 & 2 \\
\hline A04 & 0.5 & 0.33 & 0.33 & 1 & 2 & 0.5 & 0.5 & 3 & 3 & 0.5 \\
\hline A05 & 2 & 0.33 & 2 & 0.5 & 1 & 2 & 2 & 2 & 0.5 & 3 \\
\hline A06 & 2 & 0.5 & 2 & 2 & 0.5 & 1 & 3 & 2 & 2 & 2 \\
\hline $\mathrm{A} 07$ & 0.5 & 2 & 0.5 & 2 & 0.5 & 0.33 & 1 & 0.5 & 3 & 3 \\
\hline A08 & 2 & 0.5 & 0.5 & 0.33 & 0.5 & 0.5 & 2 & 1 & 3 & 0.5 \\
\hline A09 & 0.5 & 0.33 & 2 & 0.33 & 2 & 0.5 & 0.33 & 0.33 & 1 & 3 \\
\hline A10 & 0.5 & 0.5 & 0.5 & 2 & 0.33 & 0.5 & 0.33 & 2 & 0.33 & 1 \\
\hline TOTAL & 11.5 & 9.5 & 9.83 & 16.16 & 10.83 & 8.33 & 13.67 & 15.33 & 18.33 & 19 \\
\hline
\end{tabular}

Tabel 3.13 Matriks Perhitungan Eigen Vector Beban Hutang

\begin{tabular}{|l|c|c|c|c|c|c|c|c|}
\hline & A01 & A02 & A03 & A04 & A05 & A06 & A07 & A08 \\
\hline A01 & 0.09 & 0.32 & 0.06 & 0.17 & 0.03 & 0.04 & 0.13 & 0.03 \\
\hline A02 & 0.10 & 0.16 & 0.06 & 0.26 & 0.21 & 0.15 & 0.03 & 0.11 \\
\hline A03 & 0.39 & 0.32 & 0.11 & 0.26 & 0.03 & 0.04 & 0.13 & 0.11 \\
\hline
\end{tabular}




\begin{tabular}{|l|l|l|l|l|l|l|l|l|}
\hline A04 & 0.10 & 0.05 & 0.04 & 0.09 & 0.14 & 0.04 & 0.03 & 0.17 \\
\hline A05 & 0.39 & 0.05 & 0.22 & 0.04 & 0.07 & 0.15 & 0.13 & 0.11 \\
\hline A06 & 0.39 & 0.08 & 0.22 & 0.17 & 0.03 & 0.07 & 0.20 & 0.11 \\
\hline A07 & 0.10 & 0.32 & 0.06 & 0.17 & 0.03 & 0.02 & 0.07 & 0.03 \\
\hline A08 & 0.39 & 0.08 & 0.06 & 0.03 & 0.03 & 0.04 & 0.13 & 0.06 \\
\hline A09 & 0.10 & 0.05 & 0.22 & 0.03 & 0.14 & 0.04 & 0.02 & 0.02 \\
\hline A10 & 0.10 & 0.08 & 0.06 & 0.17 & 0.02 & 0.04 & 0.02 & 0.11 \\
\hline
\end{tabular}

Tabel 3.13 Matriks Perhitungan Eigen Vector Beban Hutang (lanjutan)

\begin{tabular}{|l|r|r|r|r|r|}
\hline & A09 & A10 & \multicolumn{1}{l|}{ Total } & $\begin{array}{l}\text { E. } \\
\text { Vactor }\end{array}$ & \multicolumn{1}{l|}{ Ranking } \\
\hline A01 & 0.10 & 0.08 & 1.04 & 0.10 & 6 \\
\hline A02 & 0.15 & 0.08 & 1.30 & 0.13 & 4 \\
\hline A03 & 0.02 & 0.08 & 1.50 & 0.15 & 1 \\
\hline A04 & 0.15 & 0.02 & 0.82 & 0.08 & 9 \\
\hline A05 & 0.02 & 0.13 & 1.31 & 0.13 & 3 \\
\hline A06 & 0.10 & 0.08 & 1.46 & 0.15 & 2 \\
\hline A07 & 0.15 & 0.13 & 1.07 & 0.11 & 5 \\
\hline A08 & 0.15 & 0.02 & 0.98 & 0.10 & 7 \\
\hline A09 & 0.05 & 0.13 & 0.79 & 0.08 & 8 \\
\hline A10 & 0.02 & 0.04 & 0.66 & 0.07 & 10 \\
\hline
\end{tabular}

Tabel 3.14 Matriks Kriteria Usia Berpasangan

\begin{tabular}{|l|r|r|r|r|r|r|r|r|r|r|}
\hline & \multicolumn{1}{l}{ A01 } & \multicolumn{1}{l}{ A02 } & \multicolumn{1}{l}{ A04 } & \multicolumn{1}{l}{ A05 } & A06 & A07 & A08 & A09 & A10 \\
\hline A01 & 1 & 2 & 0.5 & 2 & 2 & 3 & 2 & 0.5 & 0.5 & 2 \\
\hline A02 & 0.5 & 1 & 3 & 3 & 3 & 2 & 0.5 & 2 & 3 & 0.5 \\
\hline A03 & 2 & 0.33 & 1 & 3 & 0.5 & 0.5 & 2 & 2 & 0.5 & 2 \\
\hline A04 & 0.5 & 0.33 & 0.33 & 1 & 2 & 0.5 & 2 & 0.5 & 3 & 0.5 \\
\hline A05 & 0.5 & 0.33 & 2 & 0.5 & 1 & 2 & 2 & 2 & 3 & 3 \\
\hline A06 & 0.33 & 0.5 & 2 & 2 & 0.5 & 1 & 0.5 & 2 & 2 & 2 \\
\hline A07 & 0.5 & 2 & 0.5 & 0.5 & 0.5 & 2 & 1 & 3 & 3 & 3 \\
\hline A08 & 2 & 0.5 & 0.5 & 2 & 0.5 & 0.5 & 0.33 & 1 & 0.5 & 0.5 \\
\hline A09 & 2 & 0.33 & 2 & 0.33 & 0.33 & 0.5 & 0.33 & 2 & 1 & 0.5 \\
\hline A10 & 0.5 & 2 & 0.5 & 2 & 0.33 & 0.5 & 0.33 & 2 & 2 & 1 \\
\hline TOTAL & $\mathbf{9 . 8 3}$ & $\mathbf{9 . 3 3}$ & $\mathbf{1 2 . 3 3}$ & $\mathbf{1 6 . 3 3}$ & $\mathbf{1 0 . 6 7}$ & $\mathbf{1 2 . 5}$ & $\mathbf{1 1}$ & $\mathbf{1 7}$ & $\mathbf{1 8 . 5}$ & $\mathbf{1 5}$ \\
\hline
\end{tabular}

Tabel 3.15 Matriks Perhitungan Eigen Vector Usia

\begin{tabular}{|l|c|c|c|c|c|c|c|c|}
\hline & A01 & A02 & A03 & A04 & A05 & A06 & A07 & A08 \\
\hline A01 & 0.10 & 0.32 & 0.06 & 0.17 & 0.14 & 0.22 & 0.13 & 0.03 \\
\hline A02 & 0.10 & 0.16 & 0.33 & 0.26 & 0.21 & 0.15 & 0.03 & 0.11 \\
\hline A03 & 0.39 & 0.05 & 0.11 & 0.26 & 0.03 & 0.04 & 0.13 & 0.11 \\
\hline A04 & 0.10 & 0.05 & 0.04 & 0.09 & 0.14 & 0.04 & 0.13 & 0.03 \\
\hline A05 & 0.10 & 0.05 & 0.22 & 0.04 & 0.07 & 0.15 & 0.13 & 0.11 \\
\hline A06 & 0.06 & 0.08 & 0.22 & 0.17 & 0.03 & 0.07 & 0.03 & 0.11 \\
\hline A07 & 0.10 & 0.32 & 0.06 & 0.04 & 0.03 & 0.15 & 0.07 & 0.17 \\
\hline A08 & 0.39 & 0.08 & 0.06 & 0.17 & 0.03 & 0.04 & 0.02 & 0.06 \\
\hline A09 & 0.39 & 0.05 & 0.22 & 0.03 & 0.02 & 0.04 & 0.02 & 0.11 \\
\hline A10 & 0.10 & 0.32 & 0.06 & 0.17 & 0.02 & 0.04 & 0.02 & 0.11 \\
\hline
\end{tabular}


Tabel 3.15 Tabel Matriks Perhitungan Eigen Usia (lanjutan)

\begin{tabular}{|c|c|c|c|c|c|}
\hline & A09 & A10 & Total & $\begin{array}{c}\text { E. } \\
\text { Vector }\end{array}$ & Ranking \\
\hline A01 & 0.02 & 0.08 & 1.27 & 0.13 & 2 \\
\hline A02 & 0.15 & 0.02 & 1.51 & 0.15 & 1 \\
\hline A03 & 0.02 & 0.08 & 1.23 & 0.12 & 3 \\
\hline A04 & 0.15 & 0.02 & 0.78 & 0.08 & 10 \\
\hline A05 & 0.15 & 0.13 & 1.14 & 0.11 & 5 \\
\hline A06 & 0.10 & 0.08 & 0.97 & 0.10 & 7 \\
\hline A07 & 0.15 & 0.13 & 1.20 & 0.12 & 4 \\
\hline A08 & 0.02 & 0.02 & 0.89 & 0.09 & 9 \\
\hline A09 & 0.05 & 0.02 & 0.95 & 0.10 & 8 \\
\hline A10 & 0.10 & 0.04 & 0.97 & 0.10 & 6 \\
\hline
\end{tabular}

Tabel 3.16 Tabel Prioritas Global

\begin{tabular}{|c|c|c|c|c|c|c|c|}
\hline Nama Alternatif & $\mathrm{K} 1$ & $\mathrm{~K} 2$ & $\mathrm{~K} 3$ & $\mathrm{~K} 4$ & $\mathrm{~K} 5$ & Total & Keterangan \\
\hline $\begin{array}{c}\text { ADE IRMA HASANAH } \\
\text { LUBIS }\end{array}$ & $\mathrm{s}$ & 1 & 0,78 & 1,12 & 0,34 & 4,24 & Layak \\
\hline APRILIA WULANDARI & 3,23 & 1 & 0,49 & 0.67 & 0,37 & 6,46 & Layak \\
\hline AYU RANTIKA PUTRI & 1,41 & 1 & 0,85 & 1,57 & 0,29 & 4,69 & Layak \\
\hline $\begin{array}{c}\text { AYU RANTIKA } \\
\text { PANJAITAN }\end{array}$ & 4,52 & 1 & 0,85 & 1.34 & 0,21 & 7,22 & Layak \\
\hline INDAH SARI & 1,61 & 1 & 0,49 & 0.90 & 0,31 & 4,55 & Layak \\
\hline LISMA PUSPITA SARI & 5,65 & 1 & 0,56 & 1,34 & 0,24 & 8,65 & Layak \\
\hline NOVI PUSPA SARI & 2,51 & 0 & 0,85 & 1.46 & 0,31 & 5,11 & Layak \\
\hline ARAFAH & 1,88 & 0 & 0,78 & 1.01 & 0,18 & 4,23 & Layak \\
\hline NURMALA & 2,83 & 1 & 0,78 & 0.90 & 0,18 & 5,31 & Layak \\
\hline PUTRI NOVITA & 2,51 & 0 & 0,56 & 0,67 & 0,21 & 3,95 & Tidak Layak \\
\hline
\end{tabular}

Dari tabel diatas dinyatakan bahwa alternatif dengan kode A10 memiliki nilai tertinggi dengan angka 8.28 dan diikuti oleh alternatif dengan kode alternatif A08 dengan nilai 6.95. Berdasarkan pernyataan diatas dapat disimpulkan bahwa nilai yang lebih besar dari 4 maka dapat dinyatakan layak mendapatkan pinjaman modal usaha, sebaliknya yang mendapat nilai lebih kecil dari 4 maka tidak layak mendapatkan pinjaman atau dalam bentuk tabel dapat dilihat pada tabel berikut ini :

Tabel 3.17 Tabel Aturan Kelayakan

\begin{tabular}{|l|l|}
\hline & Keterangan \\
\hline$>4$ & Layak Mendapatkan pinjaman modal usaha \\
\hline$<4$ & Tidak layak mendapatkan pinjaman modal usaha \\
\hline
\end{tabular}

\section{IMPLEMENTASI}

Implementasimerupakan tampilan dari implementasi sistem dari Penerapan Sistem Pendukung Keputusan untuk Implementasi merupakan langkah yang digunakan untuk mengoperasikan sistem yang akan dibangun. Dalam bab ini akan dijelaskan bagaimana menjalankan sistem yang telah dibangun tersebut. Dibawah melakukan seleksi terbadap calon nasabah mendapatkan pinjaman modal usaha dengan menggunakan metode AHP.

$$
\text { 1. Tampilan Form Login }
$$


Setelah program dijalankan oleh user atau pengguna harus melakukan login terlebih dahulu dengan cara menginput username dan password sesuai dengan sistem yang telah ada pada database, jika benar user atau pengguna akan masuk kehalaman menu utama dan jka username dan password yang dimasukkan tidak sesuai maka user atau pengguna harus mengulangi untuk menginput username dan password dengan benar. Dibawah ini merupakan tampilan form login adalah sebagai berikut :

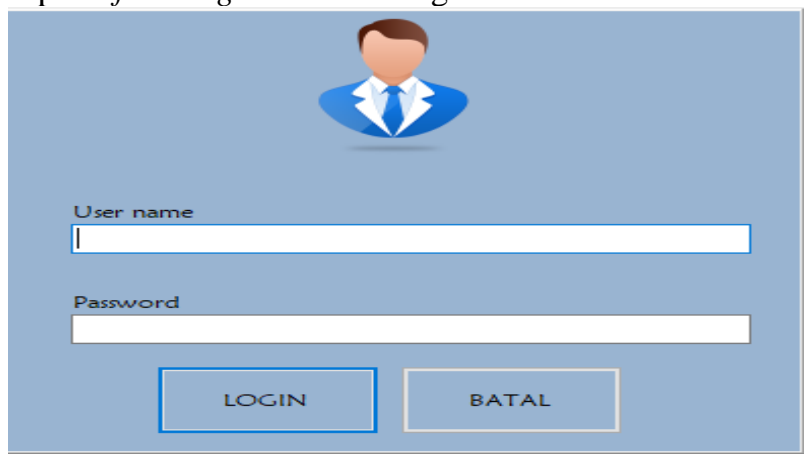

Gambar 1. Tampilan Form Login

\section{Tampilan Form Utama}

Halaman menu utama merupakan tampilan halaman awal sistem untuk melakukan pengolahan data didalam sistem pendukung keputusan menggunakan metode AHP. Berikut ini merupakan tampilan halaman menu utama :

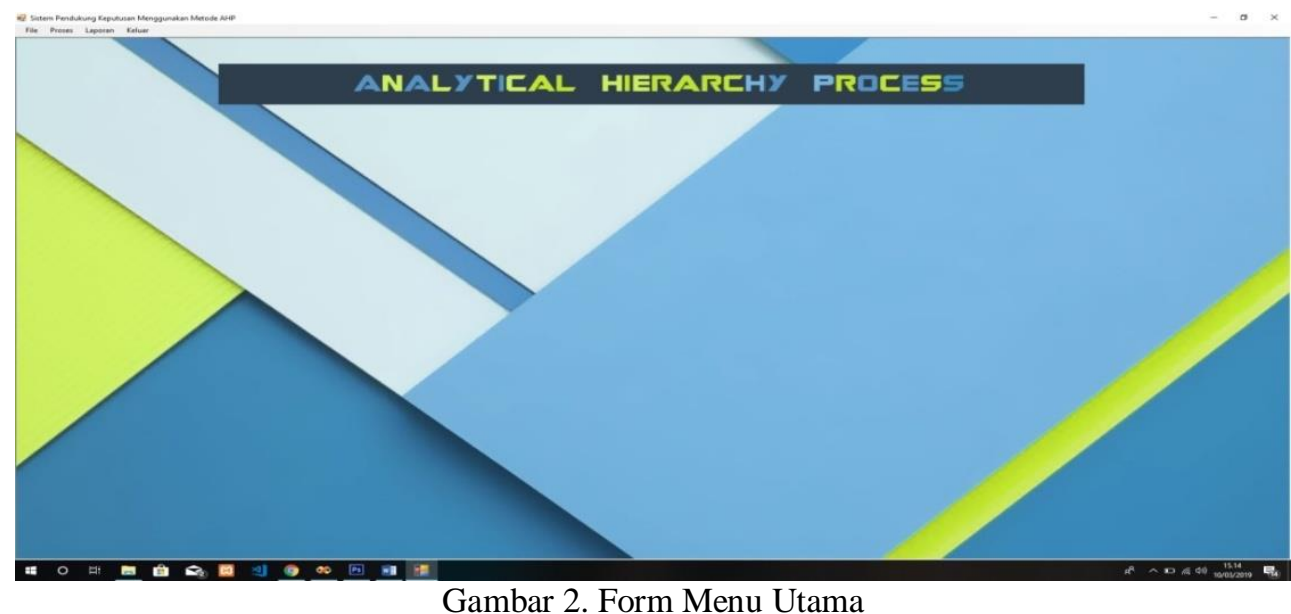

\section{Tampilan Form Data Kriteria}

Form kriteria di buat untuk menampung data kriteria yang digunakan untuk penyeleksian agar dapat menentukan alternatif yang terbaik untuk digunakan untuk menguji kelayakan penerima bantuan pinjaman modal usaha: 


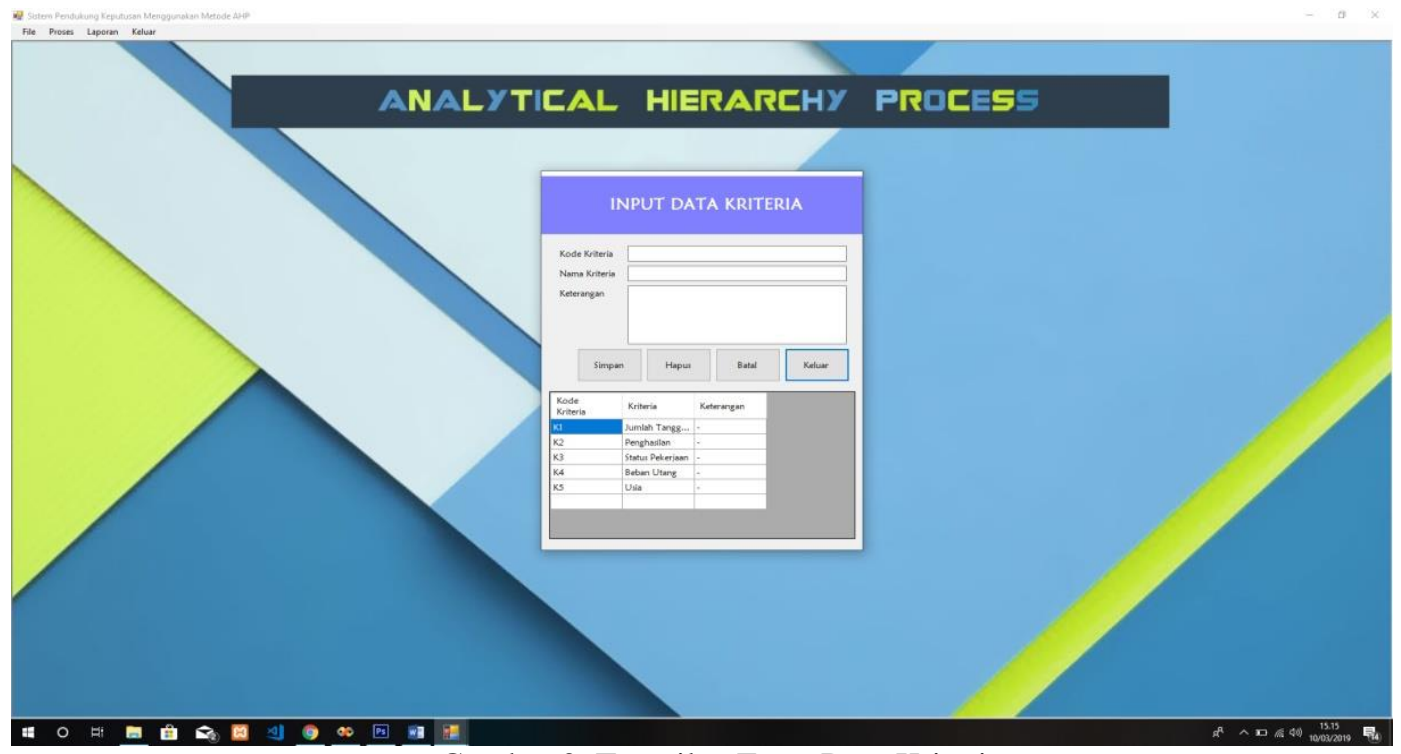

Gambar 3. Tampilan Form Data Kriteria

4. Tampilan Form Data Alternatif

Form Alternatif merupakan form untuk memasukan data Calon penerima pinjaman.Berikut ini adalah tampilan dari form data alternatif :

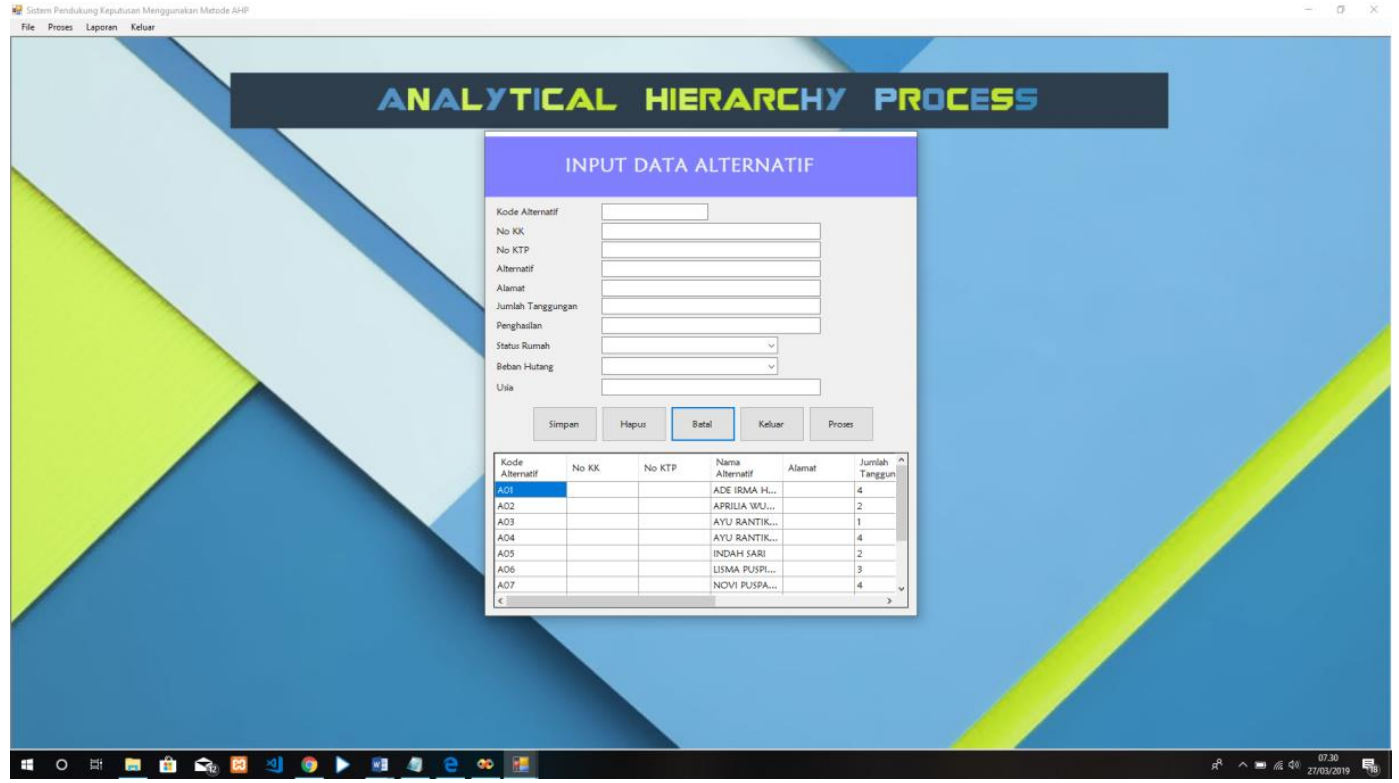

Gambar 4. Tampilan Form Data Alternatif

5. Tampilan Form Proses Keputusan

Form Proses Keputusan dilakukan untuk menghitung nilai kelayakan setiap alternatif nasabah yang akan diproses. berikut ini adalah tampilan dari form keputusan: 


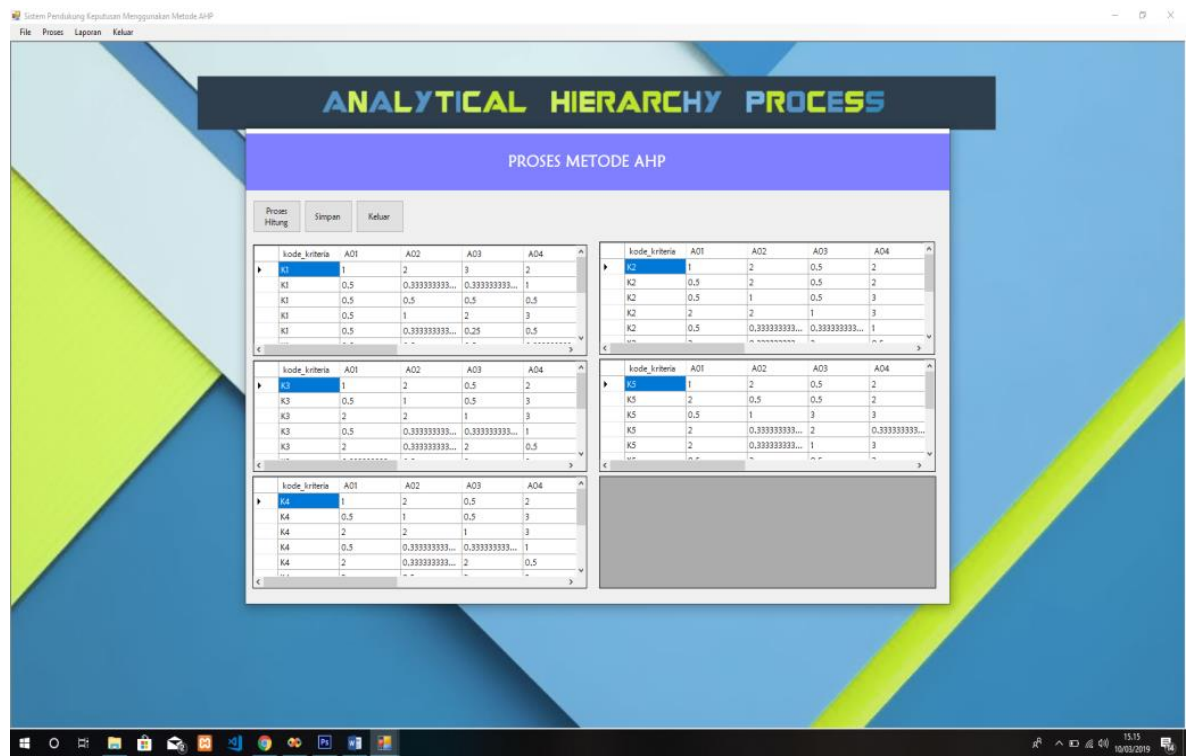

Gambar 5. Tampilan Form Proses Keputusan

6. TampilanLaporan

Form Laporan merupakan form yang digunakan untuk menampung laporan data keputusan pemilihan nasabah yang layak mendapatkan pinjaman modal usaha, berikut ini adalah tampilan dari laporan :

Form Laporan

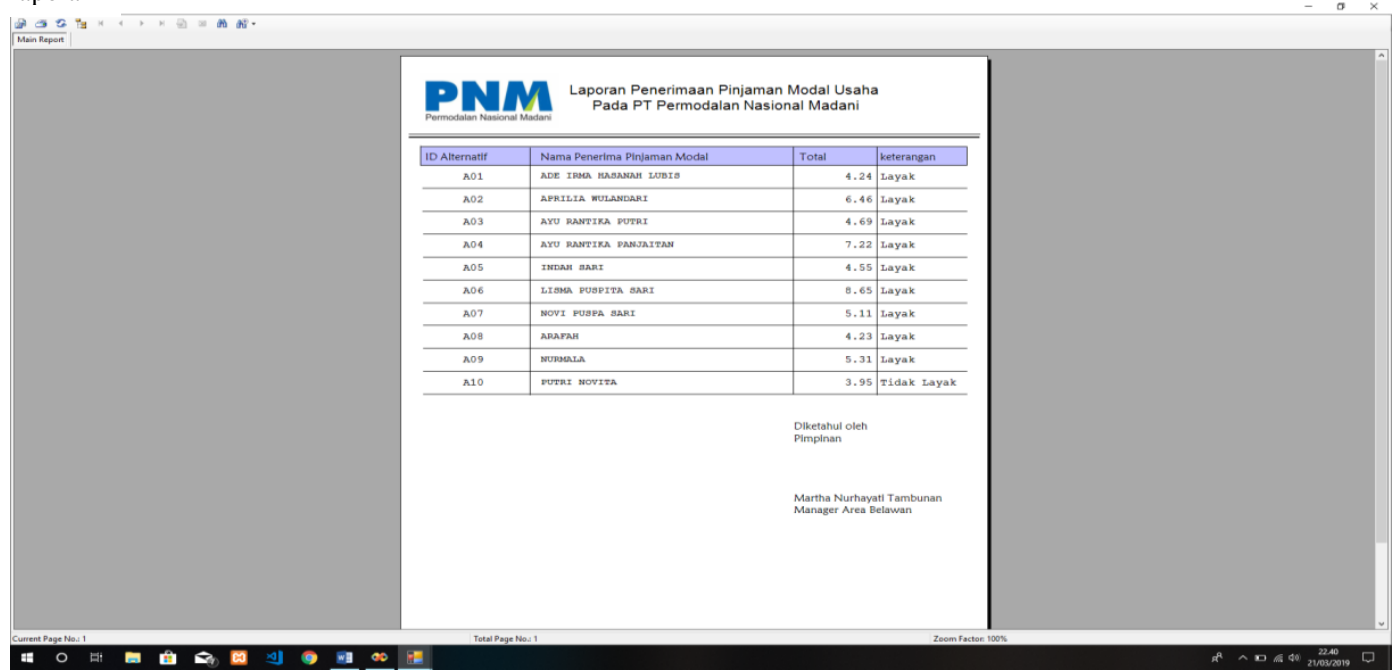

Gambar 6. Tampilan Form Laporan Kelayakan Mendapatkan Pinjaman Modal Usaha

\section{KESIMPULAN}

Berdasarkan analisa pada permasalahan yang terjadi dalam kasus yang diangkat dalam pemilihan Nasabah yang layak menerima kredit angsuran pembiayaan mekar di kecamatan Medan Belawan pada PT. Permodalan Nasional Madani menggunakan metode Analytical Hierarchy Process (AHP) maka dapat kesimpulannya sebagai berikut :

1. Bobot dari setiap kriteria dalam pemilihan Nasabah yang layak menerima kredit angsuran pembiayaan mekar di kecamatan Medan Belawan pada PT. Permodalan Nasional Madani dapat ditentukan berdasarkan tingkat kepentingan dari kriteria yang ada dengan cara matriks perbandingan yang ada dalam metode Analytical Hierarchy Process (AHP).

2. Penerapan Metode AHP pada Sistem Pendukung Keputusan untuk menentukanNasabah yang layak menerima kredit angsuran pembiayaan mekar di kecamatan Medan Belawan pada PT. Permodalan Nasional Madanidengan menentukan kriteria yaitu jumlah tanggungan, penghasilan, status rumah, beban hutang, dan usia serta menganalisis alternatif dari setiap kriteria yang telah ditentukan dan setelah itu mengimplementasikan metode Analytical Hierarchy Process (AHP). 
3. Pembuatan aplikasi sistem pendukung keputusan dirancang dengan menggunakan konsep pemodelan UML dan bahasa pemrograman basic atau lebih dikenal Visual Basic dan mengimplementasikan Metode Analytical Hierarchy Process (AHP) sehingga dapat dijadikan pemecahan masalah.

4. Hasil implementasi Sistem Pendukung Keputusan nasabah yang layak menerima kredit angsuran pada PT. Permodalan Nasional Madani di kecamatan Medan Belawan adalah yang memiliki nilai kriteria di atas 4 maka layak menerima kredit angsuran dan bernilai di bawah 4 dinyatakan tidak layak menerima kredit angsuran.

\section{DAFTAR PUSTAKA}

[1] Alif Wahyu Oktaputra, Dr., Ir Edi Noersasongko,M.Kom.Sistem Pendukung KeputusanKelayakan Pemberian Kredit Motor Menggunakan Metode Simple Additive Weighting Pada Perusahaan Leashing Hd Finance, Jurnal SPK Kelayakan Pemberian Kredit Motor 1(1), 2.

[2]Dicky Nofriansyah (2017). Multi Criteria Decision Making Yogyakarta : CV. Budi Utama.

[3] Dwi Citra Hartini1, Endang Lestari Ruskan, \& Ali Ibrahim. Sistem Pendukung Keputusan Pemilihan Hotel Di Kota Palembang Dengan Metode Simple Additive Weighting (SAW) pada Jurnal Sistem Informasi 5(1), 547.

[4]Harianto Antonio, Novi Safriadi. Rancang Bangun Sistem Informasi Administrasi Informatika (SI-ADIF) pada Jurnal ELKHA 4(2), 12

[5]Heny Pratiwi.Sistem Pendukung Keputusan Penentuan Karyawan Berprestasi Menggunakan Metode Multifactor Evaluation Process pada Jurnal Sistem Informasi 5(2), 96.

[6]Heri Nurdiyanto, Heryanita Meilia. Sistem Pendukung Keputusan penentuan Prioritas Pengembangan Industri Kecil dan Menengah Di Lampung Tengah Dengan Menggunakan Metode Analytical Hierarchy Process (AHP) Pada Seminar Nasional Teknologi Informasi dan Multimedia 2016, 38.

[7]Hetty Rohayani. Analisis Sistem Pendukung Keputusan Dalam Memilih Program Studi pada jurnal Sistem Informasi 5(1), 531.

[8]Ingot Seen Sianturi. Sistem Pendukung Keputusan Untuk Menentukan Pemilihan Jurusan Siswa dengan Menggunakan Metode Weighted Product pada Majalah Ilmiah Informasi dan Teknologi Ilmiah $1(1), 19$.

[9]Jufriadif Na'am. Sebuah Tinjauan Penggunaan Metode Analytic Hierarchy Process (AHP) dalam Sistem Penunjang Keputusan (SPK) pada Jurnal Berbahasa Indonesia, Mediasisfo 11(2), 888.

[10]Mahmud Yunus, Harry Soekotjo Dahlan, \& Purnomo Budi Santoso. SPK Pemilihan Calon Pendonor Darah Potensial dengan Algoritma C4.5 dan Fuzzy Tahani pada Jurnal EECCIS 8(1), 48. 